\title{
QUANTITATIVE ANALYSIS OF HISTAMINE IN CHEESE COLLECTED FROM KAFR EL-SHEIKH GOVERNORATE, EGYPT
}

\author{
Azza M. M. Deeb and H. F. Ahmed \\ Food Control Department, Faculty of Veterinary Medicine, Kafr El-Sheikh University, \\ Kafr El-Sheikh 33516, Egypt
}

\begin{abstract}
Forty cheese samples (20 each of Ras and Edam cheese) were randomly collected from different supermarkets at Kafr El-Sheikh Governorate, Egypt.The collected samples were homogenized and packed in polyethylene bags and stored below $-20{ }^{\circ} \mathrm{C}$ prior to quantitative analysis of Histamine (HIS) using Ridascreen Histamine (Enzyme Immunoassay for quantitative analysis of histamine). Histamine was found in 100 and 75\% of the analyzed Ras and Edam cheese samples with a total percentage of $87.5 \%$, and mean concentrations of $23.38 \pm 2.04,1.08 \pm 0.12$ and $13.82 \pm 0.46 \mathrm{mg} / 100 \mathrm{~g}$, respectively. Eighty\% of the examined Ras cheese presented a HIS concentration over $100 \mathrm{mg} / \mathrm{kg}$ the recommended upper limit for histamine. While, the concentrations of HIS in all Edam cheese samples analyzed were lower than the maximum acceptable limit. As HIS content in cheese samples of different type and origin varied to a great extent, obligatory monitoring of histamine should be considered as a valuable tool to ensure quality of cheese.
\end{abstract}

\section{INTRODUCTION}

Biogenic amines are organic bases of low molecular weight, formed in foods mainly by the microbial decarboxylation of certain amino acids and it has been suggested that their concentration can be 
used as an indicator for the hygienic quality of the food (Schneller et al., 1997; Innocente and D'agostin, 2002 and Novella-Rodriguez et al., 2002). Histamine (HIS) is one of the most studied amines arises in foods by the growth of microorganisms that possess histidine decarboxylase and thus, foods rich in free histidine contains high level of HIS.

Histamine poisoning is a chemical intoxication resulting from the ingestion of food that contain unusually high levels of HIS (Taylor, 1988). Just $75 \mathrm{mg}$ of histamine, a quantity commonly present in some meals, can induce symptoms in the majority of healthy persons with no history of HIS intolerance (Wöhrl et al., 2004).

European legislation (Commission Regulation (EC) 2073/2005) limits the histamine levels in fishery products to $200 \mathrm{mg} \mathrm{Kg}^{-1}$ for fresh fish and up to $400 \mathrm{mg} \mathrm{Kg}^{-1}$ for cured products. The US Food and Drug Administration consider it a danger to health if the HIS level is equal to $500 \mathrm{mg} \mathrm{Kg}^{-1}$ (FDA, 1995). Although there are no regulations governing the HIS content in most foodstuffs, some laboratories have made a recommendation to limit the presence of HIS to $100 \mathrm{mg} \mathrm{Kg}^{-1}$ in fermented food products (Brink et al., 1990). Although fish of the families Scombridae and Scomberesocidae are commonly implicated in incidents of HIS poisoning, non-scombroid fish, cheese and other foods have also been attributed in cases of such poisoning (Stratton et al., 1991).

The presence of biogenic amines especially HIS in cheese constitutes a potential public health concern because of its physiological and toxicological effects (Önal, 2007). HIS is a powerful biologically active chemical that can directly stimulate the heart, cause extravascular Kafrelsheikh Vet. Med. J. Vol. 8 No. 2 (2010) 
smooth muscle to contract or relax, stimulate both sensory and motor neurons, and control gastric secretion. Therefore, a wide variety of symptoms can be attributed to this type of poisoning, rash, urticaria, eodema, nausea, vomiting, diarrhea, abdominal cramps, hypotension, headache, palpitations, tingling, flushing and burning sensations in the mouth (Stratton et al., 1991).

Amine contents may vary among different types of cheese; ripened cheeses usually contain higher concentrations of amines than unripened cheeses. This difference can be related to casein proteolysis during ripening (Flick and Granata, 2004). Moreover, the duration and conditions of the ripening period and starter culture types used are important factors for the production of amines. Also, bacterial quality of milk, heat treatments applied, $\mathrm{pH}$, salt concentration, and temperature are the other parameters leading to differences among a variety of cheese (Stratton et al., 1991 and Novella-Rodriguez et al., 2003).

Due to the impact of biogenic amines on human health and food safety, monitoring their levels in foodstuffs is still gaining importance (亘al, 2007).Therefore, this study was planned to determine the presence of histamine in hard and semi-hard cheese commercially available in Kafr EL-Sheikh Governorate, Egypt.

\section{MATERIALS AND METHODS}

\section{Collection of samples}

Forty cheese samples (20 each of Ras and Edam cheese) were randomly collected from different supermarkets at Kafr El- sheikh Governorate, Egypt. All samples were analyzed before their expiry date. The collected 
samples were homogenized and packed in polyethylene bags and stored below $-20{ }^{\circ} \mathrm{C}$ prior to analysis.

2. Quantitative analysis of Histamine: using Ridascreen ${ }^{\circledR}$ Histamine (Enzyme Immunoassay for quantitative analysis of histamine), Art. No.: R1604, according to instruction of manufacturer's.

2.1. Preparation of Samples: Ten g. of cheese samples were homogenized; $9 \mathrm{ml}$ of distilled water were added to $1 \mathrm{~g}$ of homogenate and mixed well, then centrifuged for $5 \mathrm{~min} / 2500 \mathrm{~g}(6750 \mathrm{rpm})$ at room temperature $\left(20-25^{\circ} \mathrm{C}\right)$. Lipid layer was removed and $1 \mathrm{ml}$ of the supernatant was mixed well with $9 \mathrm{ml}$ of distilled water, then $200 \mu \mathrm{l}$ of this solution were diluted with $9.8 \mathrm{ml}$ of distilled water.

\subsection{Test implementation}

\subsubsection{Test preparation}

All reagents were adjusted to room temperature $\left(20-25^{\circ} \mathrm{C}\right)$ before use. The washing buffer was diluted 1:50 $(1+49)$ with distilled water before use. The acylation reagent was reached room temperature till forms a homogeneous, crystal-free solution before use.

\subsubsection{Test procedure for the acylation}

From each of the standard solution, control or prepared sample $100 \mu \mathrm{l}$ were added to separate wells of the acylation plate, $25 \mu \mathrm{l}$ of the acylation reagent were added to each acylation well then, $200 \mu \mathrm{l}$ of the acylation buffer were added to each acylation well and mixed gently by shaking the plate manually. The plate was incubated for $15 \mathrm{~min}$ at room temperature $\left(20-25^{\circ} \mathrm{C}\right)$. 


\subsubsection{Test procedure for ELISA}

Sufficient numbers of wells were inserted into the microwell holder for all standards, controls and samples. $25 \mu \mathrm{l}$ of acylated standard solution, control or prepared sample were added to separate wells. $100 \mu \mathrm{l}$ of the anti-histamine antibody solution were added to each well and mixed gently by shaking the plate manually. The plate was incubated for $40 \mathrm{~min}$ at room temperature $\left(20-25^{\circ} \mathrm{C}\right)$. The liquid was poured out of the wells and the microwell holder was taped upside down vigorously (three times in a row) against absorbent paper to ensure complete removal of liquid from the wells. All the wells were filled with $250 \mu$ l of washing buffer and the liquid was poured out again. The washing process was repeated two more times. $100 \mu \mathrm{l}$ of the conjugate solution were added to of each well and mixed gently by shaking the plate manually and incubated for 20 min at room temperature $\left(20-25^{\circ} \mathrm{C}\right)$. The liquid was poured out of the wells and the microwell holder was taped upside down vigorously (three times in a row) against absorbent paper to ensure complete removal of liquid from the wells. All the wells were filled with $250 \mu$ of washing buffer and the liquid was poured out again. The washing process was repeated two more times. $100 \mu \mathrm{l}$ of the substrate-/chromogen solution were added to each well and mixed gently by shaking the plate manually and incubate for $15 \mathrm{~min}$ at room temperature $\left(20-25^{\circ} \mathrm{C}\right)$ in the dark. 100 $\mu \mathrm{l}$ of the stop solution were added to each well, mixed gently by shaking the plate manually and the absorbance was measured at $450 \mathrm{~nm}$ against an air blank within 10 min after addition of stop solution. 


\subsubsection{Calculation}

The absorbance values obtained for the standards and the samples were divided by the absorbance value of the first standard (zero standard) and multiplied by 100 . The zero standard is thus made equal to $100 \%$ and the absorbance values are quoted in percentages. The absorption is inversely proportional to the HIS concentration in the sample. The histamine concentration in $\mu \mathrm{g} / \mathrm{kg}$ (ppb) corresponding to the absorbance of each sample was read from the calibration curve and then further multiplied by the dilution factor (5000). According to the test preparation record, the lower detection limit is $2.5 \mathrm{ppm}$ and the recovery rate is $100 \%$ for cheese.

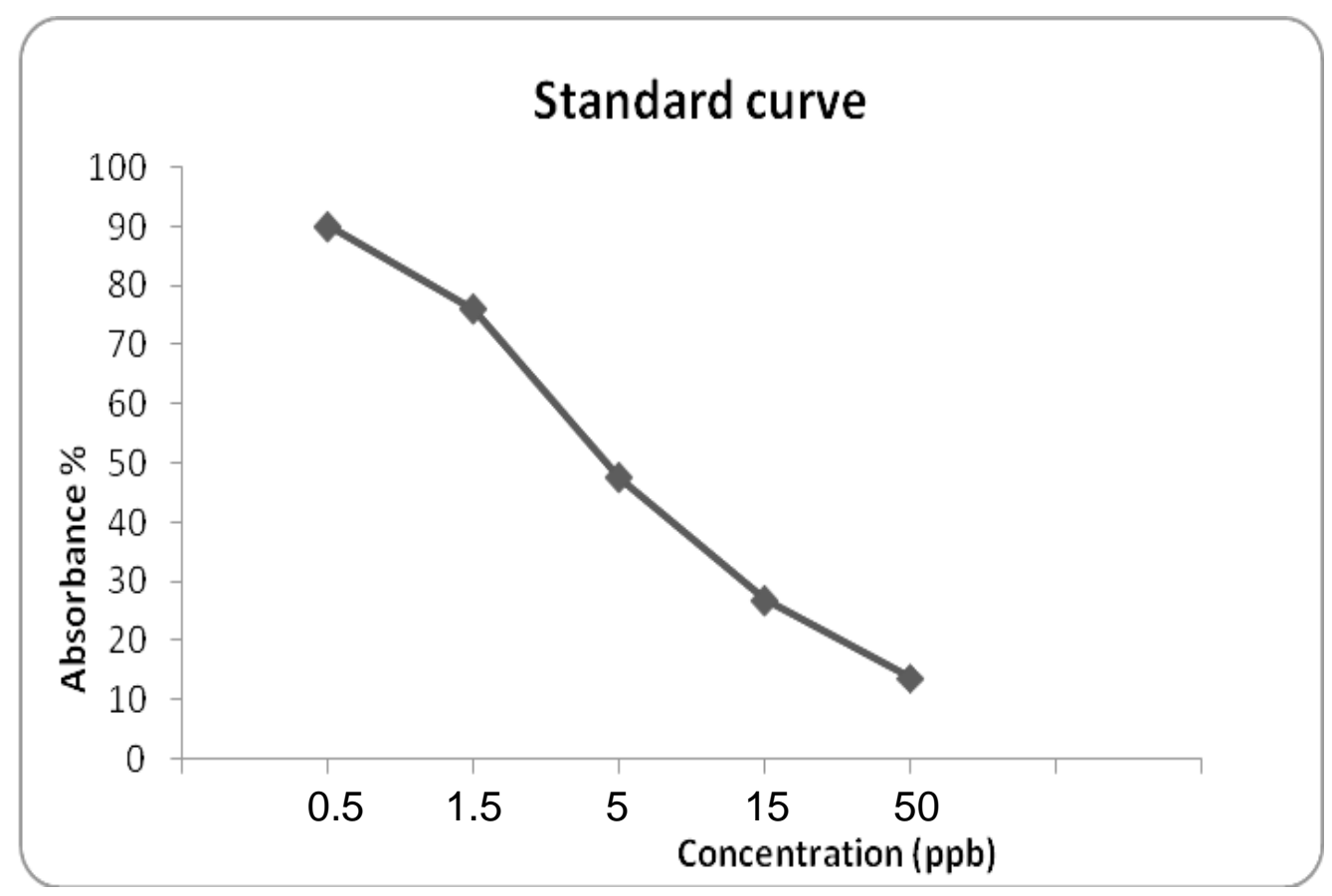

$\overline{\overline{\text { Kafrelsheikh Vet. Med. J. Vol. } 8 \text { No. } 2 \text { (2010) }}}$ 


\section{RESULTS}

Table (1): Concentration of histamine $(\mathrm{mg} / 100 \mathrm{~g})$ in the examined cheese samples.

\begin{tabular}{|c|c|c|c|c|c|c|}
\hline \multirow{2}{*}{$\begin{array}{l}\text { Types of } \\
\text { samples }\end{array}$} & \multirow{2}{*}{$\begin{array}{c}\text { No. of examined } \\
\text { samples }\end{array}$} & \multicolumn{2}{|c|}{ Positive samples } & \multicolumn{3}{|c|}{ Concentration $\mathrm{mg} / 100 \mathrm{~g}$} \\
\hline & & No. & $\%$ & Min. & Max. & $\operatorname{Mean} \pm \mathrm{SE}$ \\
\hline Ras cheese & 20 & 20 & 100 & 1.4 & 33.3 & $23.38 \pm 2.04$ \\
\hline Edam cheese & 20 & 15 & 75 & 0.25 & 2.3 & $1.08 \pm 0.12$ \\
\hline Total & 40 & 35 & 87.5 & 0.25 & 33.3 & $13.82 \pm 0.46$ \\
\hline
\end{tabular}

Table (2): Frequency distribution of examined cheese samples based on their histamine concentration.

\begin{tabular}{||c||c||c||c|c||}
\hline \multicolumn{1}{|c||}{ Frequency } & \multicolumn{2}{|c||}{ Ras cheese } & \multicolumn{2}{c|}{ Edam cheese } \\
\cline { 2 - 5 } & No. & $\%$ & No. & $\%$ \\
\hline \hline $0-5$ & 1 & 5 & 15 & 100 \\
$>5-10$ & 3 & 15 & 0 & 0 \\
$>10-20$ & 1 & 5 & 0 & 0 \\
$>20$ & 15 & 75 & 0 & 0 \\
\hline \hline Total & $\mathbf{2 0}$ & $\mathbf{1 0 0}$ & $\mathbf{1 5}$ & $\mathbf{1 0 0}$ \\
\hline
\end{tabular}

\section{DISCUSSION}

Society is increasingly aware of the importance of diet for health, and hence, any issue relating to food safety has a considerable impact on consumer behaviour and official policy. A great effort has been made in the development of techniques to detect contaminants, such biogenic 
amines, in foodstuffs. Histamine poisoning is a food-borne chemical intoxication caused by the ingestion of HIS (mainly by the intake of scombroid fish or cheeses, rich in HIS) and is the most common foodborne problem caused by biogenic amines. Different regulatory laws in the USA and the EU have established an upper limit of $100 \mathrm{mg} / \mathrm{kg}$ of histamine in fishery products and this is the tolerance level recommended by other research institutions for fermented foods (Brink et al., 1990).

In this work, random samples of commercial available hard (Ras) and semi hard (Edam) cheeses made with different ripening periods were analyzed for their HIS concentrations. HIS was found in 100 and $75 \%$ of the analyzed Ras and Edam cheese samples with total percentage of $87.5 \%$, and mean concentrations of $23.38 \pm 2.04,1.08 \pm 0.12$ and $13.82 \pm$ $0.46 \mathrm{mg} / 100 \mathrm{~g}$, respectively. Nearly similar result was reported by Antila et al (1984), while lower result was obtained by Ekbal and Amer (2010). Eighty\% of the examined Ras cheese presented a HIS concentration over $100 \mathrm{mg} / \mathrm{kg}$, the recommended upper limit for HIS as reported by Durlu-Özkaya et al (1999) and Durlu-Özkaya (2002). While, the concentrations of HIS in all Edam cheese samples analyzed were lower than the maximum acceptable limit.

The ageing of cheese is one of the factors that conditioned HIS formation. Cheeses with a short ageing period presented the lowest amounts of HIS than other types of cheese with long ageing period (Artur et al., 2002). Darwish (1993) reported that the HIS formation in Pannonia and Karavan cheeses starting from the third month of ripening and the HIS content increased in both types of cheeses while they matured, this explain the difference in HIS concentrations in Ras and 
Edam cheese in our study. Also, the difference in HIS concentrations may be attributed to storage of Ras cheese in Egypt at room temperature. Joosten (1988) studied the factors influencing the amounts of biogenic amines in cheese and found that histamine formation was accelerated if the cheese stored at high temperatures $\left(18^{\circ} \mathrm{C}\right.$ or $\left.21^{\circ} \mathrm{C}\right)$.

Levels above $500-1000 \mathrm{mg} / \mathrm{kg}$ for HIS are considered potentially dangerous to human health (Brink et al., 1990). Considering this, non of the examined cheese samples can be considered potentially dangerous for the consumers. However, some cheese-related cases of HIS intoxication involving individuals on drug therapy (e.g. isoniazid) have been reported after consumption of cheese containing less than 300 $\mathrm{mg} / \mathrm{kg}$ (Brink et al., 1990 and Stratton et al., 1991).

Cheese is probably one of the most important HIS sources of our diet. Probably is unavoidable to elaborate aged cheese without containing a certain amount of these biogenic amines, but is necessary to prevent the formation of high amount that may suppose a risk for the health of the consumers. Therefore, producers must reduce the amounts of contaminating microorganisms, such as enterococci or enterobacteriaceae through pasteurization and appropriate post-pasteurization hygienic measures. Biogenic amine levels are significantly lower in cheeses elaborated from pasteurized milk (Schneller et al., 1997). The use of appropriate starter cultures, which able to compete with the amine-forming microorganisms. Proper storage temperature is the most effective method to prevent HIS formation in cheese

As histamine content in cheese samples of different type and origin varied to a great extent, obligatory monitoring of histamine should be considered as a valuable tool to ensure quality of cheese. 


\section{REFERENCES}

- Antila, P.V.; Mathila,J. and Hakkarainen, (1984): Biogenic amines in cheese. 1. Determination of biogenic amines in finnish cheese using HPLC. Milchwissenschaft,39:81-85.

- Artur, X. R.; Angélica P. M. and Manuela H.H. (2002). Histamine and tyramine-forming microorganisms in Spanish traditional cheeses. Eur Food Res Technol 215:96-100.

- Brink, B.T.; Damink, C.; Joosten, H.M.; Huis I. and Veld, J.H.J. (1990). Occurrence and formation of biologically active amines in foods. Int J Food Microbiol 11:73-84.

- Commission Regulation (EC), 2073(2005). Commission regulation (EC) No. 2073/2005 of 15 November 2005 on microbiological criteria for foodstuffs. Official Journal of the European Union L338, pp. 126.

- Darwish, S.M. (1993). Development of biogenic amines in Hungarian hard cheese during ripening. Egypt. J. Dairy Sci. 21, 313-319.

- Durlu-Özkaya, F. (2002). Biogenic amine content of some Turkish cheeses. J. Food Process Preserv. 26: 259-265.

- Durlu-Özkaya, F.; Alichanidis, E.; Litopoulou- Tzanetaki, E. and Tunail, N. (1999). Determination of biogenic amine content of Beyaz cheese and biogenic amine production ability of some lactic acid bacteria. Milchwissenschaft 54: 680-682. 
- Ekbal, M.A. Ibrahim and Amer, A.A. (2010): Comparison of biogenic amines levels in different processed cheese varieties with regulatory specifications. World J. of Dairy \& Food Sciences, 5(2):127-133.

- FDA "Food and Drug Administration, USA" (1995): Decomposition and histamine-raw frozen tuna and mahi-mahi; canned tuna; and related species; availability of revised compliance policy guide. Federal Registration, 149, 39754-39756.

- Flick, G. J. and Granata, L. A. (2004). Biogenic amines in foods. In "Toxins in food". pp. 121-154. Dąbrowski, W. M. and Sikorski, Z. E. eds. CRC Press. US

- Innocente, N. and D'agostin, P. (2002). Formation of biogenic amines in a typical semihard Italian cheese. J. Food Prot. 65: 14981501.

- Joosten, H.M. (1988). Conditons allowing the formation of biogenic amines in cheese. 3 factors influencing the amongs formed. Neth. Milk Dairy J., 41:329-357.

- Novella-Rodríguez, S; Veciana-Nogués, M. T;, Trujillo-Mesa, A. J. and Vidal-Carou, M. C. (2002). Profile of biogenic amines in goat cheese made from pasteurized and pressurized milks. J. Food Sci. 67: 2940-2944.

- Novella-Rodríguez, S.; Veciana-Nogués, M. T.; Izquierdo-Pulido, M. and Vidal Carou, M. C. (2003). Distribution of biogenic amines and polyamines in cheese. J. Food Sci. 68: 750-755. 
- Önal, A. (2007). A review: Current analytical methods for the determination of biogenic amines in foods. Food Chem. 103: 14751486.

- Schneller, R.; Good, P. And Jenny, M. (1997). Influence of pasteurized milk, raw milk and different ripening cultures on biogenic amine concentrations in semi-soft cheese during ripening. Z. Lebens. Unters. Forsch. A 204, 265-272.

- Stratton, J. E.; Hutkins, R. W. and Taylor, S. L. (1991). Biogenic amines in cheese and other fermented foods: A review. J. Food Prot. 54: 460-470.

- Taylor, S.L. (1988). Marine toxins of microbial origin. Food Technol. 3, 94- 98 .

- Wöhrl, S.; Hemmer, W.; Focke, M.; Rappersberger, K. and Jarisch, $\boldsymbol{R}$. (2004). Histamine intolerance-like symptoms in healthy volunteers after oral provocation with liquid histamine, Allergy and Asthma Proceedings 25 (2004), pp. 305-311. View Record in Scopus | Cited By in Scopus (24) 
التحليل الكمى للاهستامين فى الجبن المجمع من محافظة كفر الثيخ - مصر

\section{عزه مرغنى محمد ديب سام فاروق أحمد}

قسم مراقبة الأغذية ـ كلية الطب البيطري / جامعة كفر الثيخ

تم تجميع 40 عينة عشوائية من الجين الراس والجبن الفلهنك (20 عينة من كل نوع) من

أسواق مدينة كفرالثيخ لفصصها لنقير تركيز الهيتامين بها با ستخدام اختبار الاليزا، ولقد تبين من الدراسة وجود الهيتامين بنسبة 100\% فى عينات الجين الراس ونسبة 75\% فى عينات الجين الفلكنك (بنسبة كلية 87.5\%) وقد كان متوسط تركيز الهستامين 23.38+ 2.04 و1.08+ـ 0.12 (13.82+ 0.46) مليجرام/100 جم علي التوالي0 وقد أظهرت الدراسة أن 80\% من عينات الجبن الراس قد إحتوت على كمية هيثامين أعلى من الحد المسموح به (100مجم/كجم)، بينما كان تركيز الهيثامين فى جميع عينات الجين الفلمنك أقل من الحد المسموح به هذا وقد تم مناقثتة الأهمية الصحية من تواجد الهستامين فى الجين وكيفية الحد من وجوده بها. 